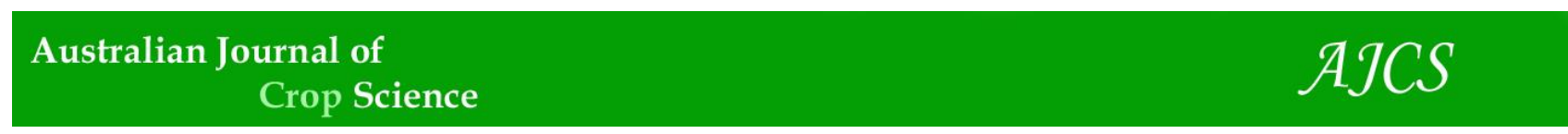

AJCS 10(11):1516-1522 (2016)

ISSN:1835-2707

doi: 10.21475/ajcs.2016.10.11.PNE44

\title{
Comparative leaf, stem and root anatomies of taxa Marrubium bourgaei and Marrubium heterodon (Lamiaceae)
}

\author{
Hatice Nurhan Büyükkartal $^{1}$, Hatice Çölgeçen ${ }^{2 *}$, Gencay Akgül ${ }^{3}$ \\ ${ }^{1}$ Ankara University, Faculty of Science, Department of Biology, 06100, Ankara,TURKEY \\ ${ }^{2}$ Bülent Ecevit University, Faculty of Arts and Sciences, Department of Biology, 67100, Zonguldak, TURKEY \\ ${ }^{3}$ Nevşehir Hacı Bektaş Veli University, Faculty of Arts and Sciences, Department of Biology, Nevşehir, TURKEY
}

*Corresponding author: haticecolgecen@gmail.com, colgecen@beun.edu.tr

\begin{abstract}
Marrubium genus is represented by 19 taxa in Flora of Turkey (19 species, 3 subspecies). 11 out of 22 taxa are endemic for Turkey and rate of endemism is 52\%. Anatomical, histological and cytological features of the leaf, stem and root in Marrubium bourgaei and M. heterodon taxa of genus Marrubium L. from Lamiaceae family were studied and taxonomic significances were identified. The leaves were amphistomatic and hypostomatic. Stomata were amaryllis type and anomocytic as indicated by neighbouring cells. The leaves of the examined Marrubium species were bifacial (dorsiventral) and a high number of prismatic crystals were observed in the leaf mesophyll tissue. The stems were angular and stomata were observed in local areas of epidermis. The underneath of stem epidermis were a few layers of collenchyma cells. In leaf cross sections, protective tissue was comprised of periderm and a nucleus at the center consisting of tracheids.
\end{abstract}

Keywords : Lamiaceae, Marrubium, plant anatomy.

Introduction

Marrubium L. genus belongs to Lamiaceae family, the members of which are distributed across the regions associated with a Mediterranean climate, particularly Southwest Asia, Cap region and Madagascar, tropical regions of Australia and China, Mexican region in North America and Chile coasts in South America (Hedge, 1992). Lamiaceae family is represented by about 200 genera and 3200 species and exists in all terrestrial ecosystems except polar regions. Salvia, Scutelleria and Stachys genera of this family are classified as cosmopolitan plants as they have worldwide distribution. Marrubium, Micromeria, Phlomis, Rosmarinus, Sideritis and Thymus genera of this family mostly occur in Mediterranean basin. The presence of limited species in tropical regions indicate that the family mostly shows existence in mild regions. The rich content of aromatic compounds and volatile oils in members of this family has made them popular since ancient times. (Heywood, 1978). Marrubium L. of the Lamiaceae family mostly includes herbaceous plants and shows distribution across IranoTuranian and Mediterranean phytogeographical regions (Hedge, 1992). Mediterranean basin, Southwest Asia and in particular, Anatolia are the richest regions in terms of species density and endemic species. There is a total of 188 records for the members of the genus being mostly in Anatolia and in Iran, Russia and Europe (Tutin, 1965; Komarov, 1964; Seybold, 1978; Akgül, 2008). Most of these became synonymous. At present, the genus has about 40 species. These species are endemic to mild regions of Euroasia, Europe, Middle East and Mediteranean. Most of the species are distributed across Irano-Turanian phytogeographical region followed by Mediterranean (Hedge, 1992). Some of the Marrubium species are used for multiple purposes due to their medicinal value and have an important place in beekeeping due to their nectar content (Komarov, 1964). Some Marrubium species (like M. vulgare) are planted in orchards for ornamental purposes. Marrubium is also used in beekeeping. Mentholated leaves of the plant are used as spice and tea. Additionally, alcohol-free drinks, puddings, jellies and chewing gums contain small amounts of Marrubium extracts (Leung, 1980; Clive and Stace, 1980; Estilai and Hatemi, 1990). Marrubium is also used for relieving dry cough as it promotes expectoration and mucus secretion by relaxing bronchial muscles. This effect is possibly attributed to marrubiin and volatile oil content of the plant. Sesquiterpenes, marrubiin and premarrubiin, promote secretion of saliva and gastric juice, which results an appetizing effect. Marrubiin is broken down in the intestine. By opening of the lactone ring, marrubiic acid is formed, which has been shown to have a strong choleretic effect and help digestion (Leung, 1980, Foster and Ducle, 1990). The revision of Marrubium genus for Turkey was made by Akgül (Akgül, 2004) and the number of species increased to 21 with the addition of two new species. Anatomical features of the leaf, stem and root in Marrubium bourgaei and M. heterodon taxa of genus Marrubium L. were examined by light microscopy and transmission electron microscopy (TEM) in the present study. Based on these examinations, it was aimed to identify morphological, histological and cytological differences and contribute to the solution of taxonomic problems of Marrubium L. genus.

\section{Results}

Leaf, stem and root anatomy in Marrubium bourgaei:

Leaf anatomy: The samples of Marrubium bourgaei were 
Table 1. Leaf anatomical feautures in taxa Marrubium bourgaei and M. heterodon.

\begin{tabular}{|c|c|c|c|c|c|c|c|c|}
\hline & $\begin{array}{l}\text { Leaf Lower } \\
\text { Surface } \\
\text { Number of } \\
\text { Epidermis } \\
\left(\text { per } \mathrm{mm}^{2}\right) \\
\end{array}$ & $\begin{array}{l}\text { Leaf Lower } \\
\text { Surface } \\
\text { Number of } \\
\text { Stomata } \\
\left(\text { per } \mathrm{mm}^{2}\right) \\
\end{array}$ & $\begin{array}{l}\text { Lower } \\
\text { Surface } \\
\text { Stomatal } \\
\text { Index }\end{array}$ & $\begin{array}{l}\text { Leaf Upper } \\
\text { Surface } \\
\text { Number of } \\
\text { Epidermis } \\
\left(\text { per } \mathrm{mm}^{2}\right) \\
\end{array}$ & $\begin{array}{l}\text { Leaf Upper } \\
\text { Surface } \\
\text { Number of } \\
\text { Stomata } \\
\left(\text { per } \mathrm{mm}^{2}\right) \\
\end{array}$ & $\begin{array}{l}\text { Upper } \\
\text { Surface } \\
\text { Stomatal } \\
\text { Index }\end{array}$ & $\begin{array}{l}\text { Stomata } \\
1 \text { Index } \\
\text { Ratio }\end{array}$ & $\begin{array}{l}\text { Mesophyll } \\
\text { thickness } \\
(\mu \mathrm{m})\end{array}$ \\
\hline $\begin{array}{l}\text { Marrubium } \\
\text { bourgaei* }^{*}\end{array}$ & - & - & - & - & - & - & - & 265 \\
\hline $\begin{array}{l}\text { Marrubium } \\
\text { heteredon }\end{array}$ & 500 & 102 & 16.94 & 700 & 100 & 12.5 & 0.73 & 200 \\
\hline
\end{tabular}

*However, no counts of epidermis and stomata could be performed in the surface sections of $M$. bourgaei due to intense cover of glandular and eglandular hairs

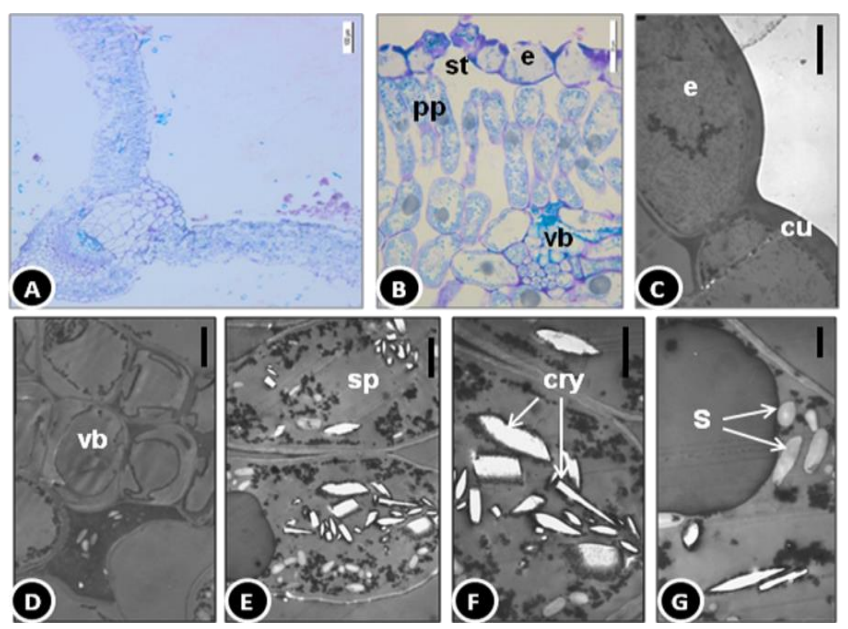

Fig 1. Leaf anatomical structure in Marrubium bourgaei (leaf cross sections). A. General appearance of leaf cross section Bar $=100$ $\mu \mathrm{m}$. B. Stoma cells and small vascular bundle Bar $=20 \mu \mathrm{m}$. C. Electron micrography of epidermis cells Bar $=1 \mu \mathrm{m}$. D. Electron micrography of vascular bundle Bar $=1 \mu \mathrm{m}$. E. Sponge parenchyma cells Bar $=1 \mu \mathrm{m}$. F. Prismatic crystals (arrows) in sponge parenchyma cells Bar $=2 \mu \mathrm{m}$. G. Starch grains in sponge parenchyma (arrows) $B a r=2 \mu \mathrm{m}$.

Table 2. Marrubium taxa used for examination of the root, stem and leaf structures.

\begin{tabular}{lll}
\hline Taxon name & Population No & Sampling Location \\
\cline { 2 - 3 } Marrubium bourgaei & G.Akül 3500 & Antalya, Merkez, Kar çukuru \\
Marrubium heterodon & G. Akgül 3600 & Adana, Pozant1, Karadağ \\
\hline
\end{tabular}
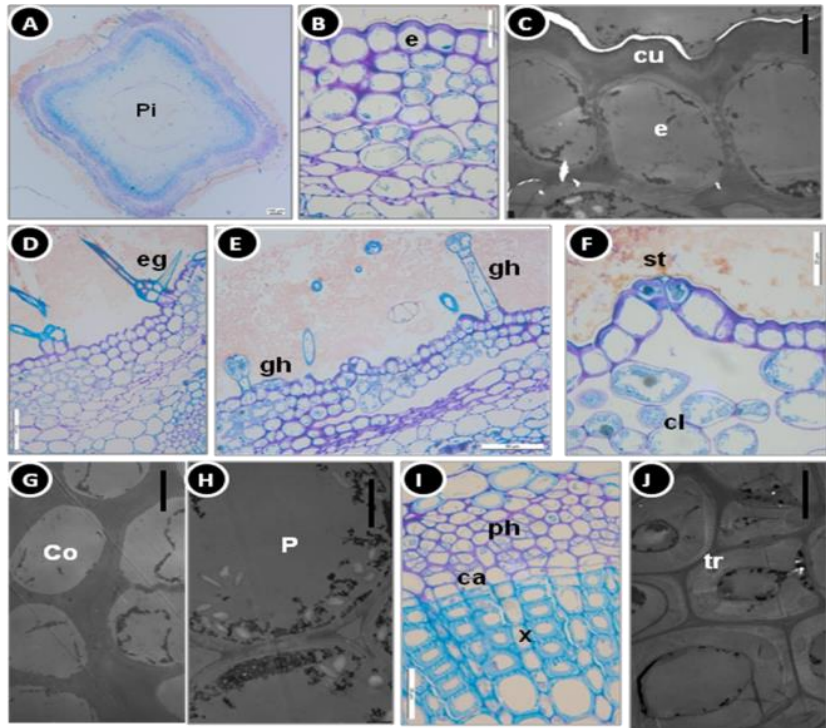

Fig 2. Stem anatomical structure in Marrubium bourgaei (stem cross section). A. General appearance of the stem Bar $=100 \mu \mathrm{m}$. B. Epidermis cells Bar $=20 \mu \mathrm{m}$. C. Electron micrography of epidermis cells Bar $=1 \mu \mathrm{m}$. D. Eglandular hairs Bar $=50 \mu \mathrm{m}$ E. Glandular hairs Bar $=50 \mu \mathrm{m}$ F. Stoma Bar $=20 \mu \mathrm{m}$ G. Electron micrography of collenchyma cells Bar $=1 \mu \mathrm{m}$. H. Electron micrography of starch-containing parenchyma cells Bar $=3 \mu \mathrm{m}$. I. Cambium cells Bar $=3 \mu \mathrm{m}$. J. Electron micrography of xylem elements $\mathrm{Bar}=3 \mu \mathrm{m}$. 


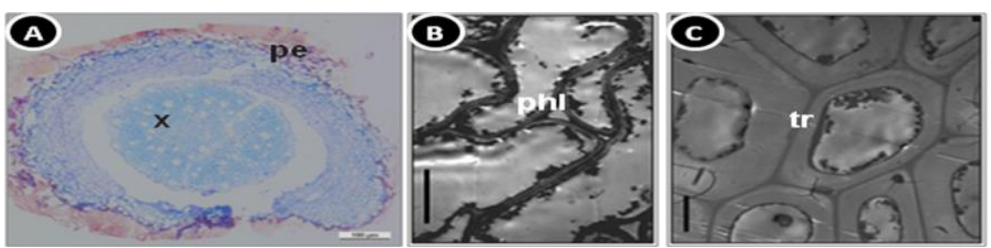

Fig 3. Root anatomical structure in Marrubium bourgaei (root cross sections). A. General apperance of the root Bar $=100 \mu \mathrm{m}$. B. Electron micrography of phellem cells Bar $=5 \mu \mathrm{m}$. C. Electron micrography of tracheid cells Bar $=5 \mu \mathrm{m}$.

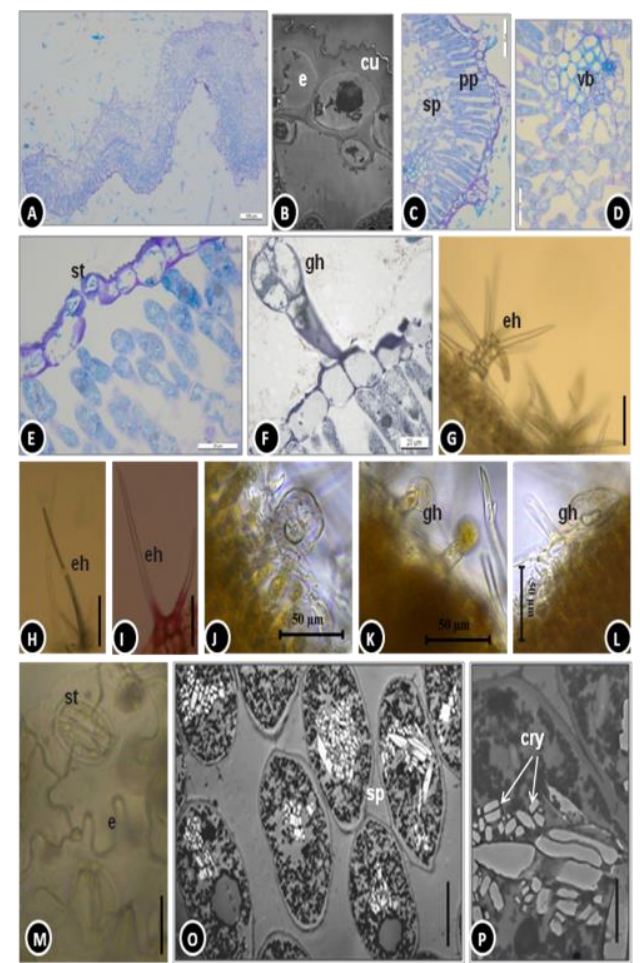

Fig 4. Leaf anatomical structure in Marrubium heterodon (leaf cross sections and surface sections). A. General appearance of leaf cross section Bar $=100 \mu \mathrm{m}$. B. Electron micrography of epidermis cells Bar=5 $\mu \mathrm{m}$. C. Leaf mesophyll Bar=50 $\mu \mathrm{m}$. D. Vascular bundle Bar=20 $\mu \mathrm{m}$. E. Stoma cells Bar=20 $\mu \mathrm{m}$. F. Glandular hair Bar=20 $\mu \mathrm{m}$. G-I. Eglandular hairs Bars=50 $\mu \mathrm{m}$. J-L. Glandular hairs of different types Bars $=50 \mu \mathrm{m}$. M. Wavy-walled epidermis and stoma in lower surface Bar=50 $\mu \mathrm{m}$. O. Sponge parenchyma cells Bar $=5 \mu \mathrm{m}$. H. Prismatic crystals (arrows) in sponge parenchyma cells $\mathrm{Bar}=2 \mu \mathrm{m}$.
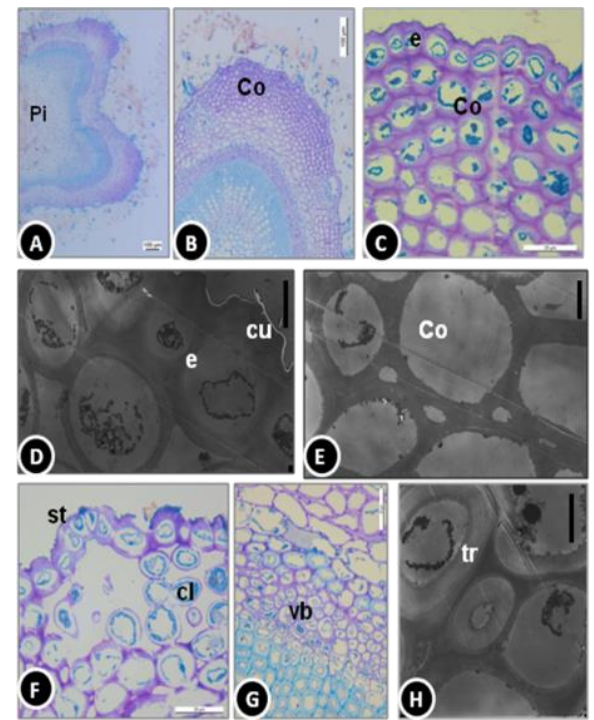

Fig 5. Stem anatomical structure in Marrubium heterodon (stem cross section). General appearance of the angular stem Bar $=100$ $\mu \mathrm{m}$. B. Collenchyma Bar $=100 \mu \mathrm{m}$. C. Enlarged photo of collenchyma Bar $=20 \mu \mathrm{m}$. D. Electron micrography of epidermis cells Bar $=5 \mu \mathrm{m}$. E. Electron micrography of collenchyma cells Bar $=1 \mu \mathrm{m}$. F. Stoma cells Bar $=20 \mu \mathrm{m}$. G. Vascular bundle Bar $=20 \mu \mathrm{m}$. H. Electron micrography of xylem elements Bar $=3 \mu \mathrm{m}$. 


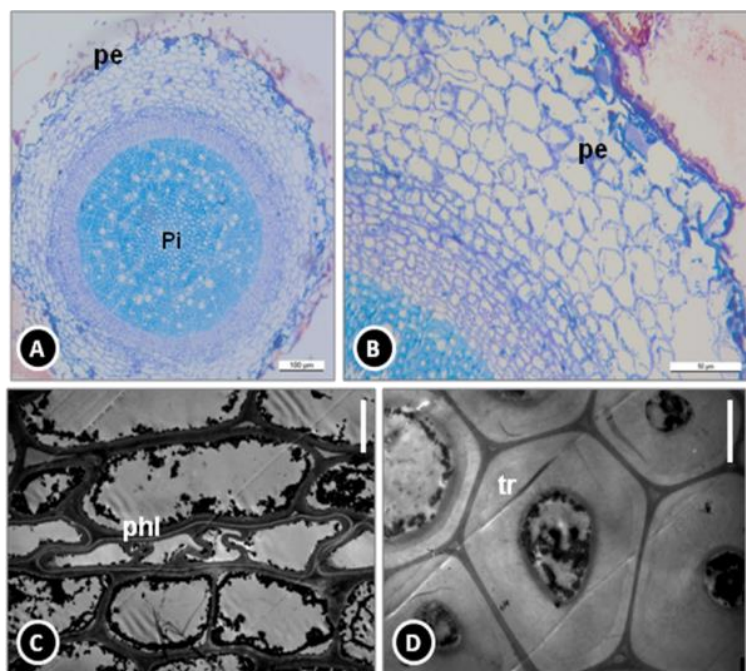

Fig 6. Root anatomical structure in Marrubium heterodon (root cross sections). General apperance of the root Bar $=100 \mu \mathrm{m}$. B. Periderm Bar $=50 \mu \mathrm{m}$. C. Electron micrography of phellem cells Bar $=5 \mu \mathrm{m}$. D. Electron micrography of tracheid cells Bar $=1 \mu \mathrm{m}$.
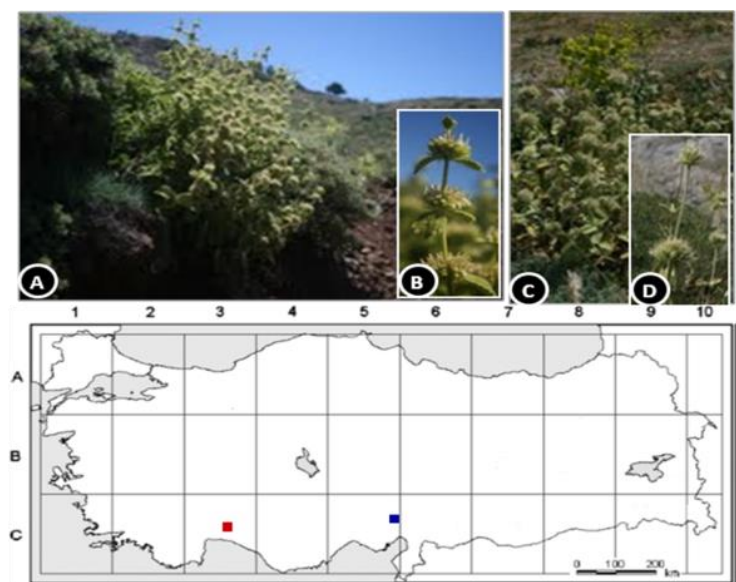

Fig 7A-B. General appearance of Marrubium bourgaei and C-D. Marrubium heterodon plants in bloom and its distribution map (ロMarrubium bourgaei, $\mathbf{\square}$ Marrubium heterodon).

collected from Kar çukuru locality situated at Bey Mountains in Antalya province of Turkey. In leaf cross section examinations, leaves were bifacial (dorsiventral) (Figure 1A). 2-3 layers of collenchyma cells were found in the midrib located between the upper and lower epidermis. A single layer of palisade parenchyma cells was observed in the mesophyll tissue composed of palisade and sponge parenchyma cells located beneath the upper epidermis consisting of large cells. Beneath the mesophyll tissue were 1-2 layers of sponge parenchyma with large intercellular spaces. The leaves were amphistomatic. Small vascular bundles were embedded in the mesophyll and they were collateral type (Figure 1B). Leaf mesophyll thickness was $265 \mu \mathrm{m}$ (Table 1). A thick cuticula was observed outside the epidermis in TEM examinations (Figure 1C). Tracheids in vascular bundles were small and thick-walled (Figure 1D). A high number of starch grains and prismatic crystals were observed in the sponge parenchyma cells with large intercellular spaces (Figures 1E-G).

Stem anatomy: In the cross section, the stem was angular and surrounded by a single layer of rectangular epidermis with a thick cuticula (Figure 2A) Lower and upper tangential walls of epidermis cells were thickened (Figures 2B and C). Multicellular branched eglandular (Figure 2D) and glandular hairs were seen (Figure 2E). In the stem cross sections, stomata were observed in local areas of epidermis (Figure 2F). 2-3 layers of lamellar collenchyma were seen beneath the epidermis (Figure 2G). Starch-containing parenchyma cells had large vacuoles (Figure $2 \mathrm{H}$ ). Vascular bundles were collateral type. Beneath the cortex parenchyma, small groups of phloem sclerenchyma cells were located above the phloem. 2-3 layers of vascular cambium were located below the phloem (Figure 2I). Xylem elements were thick-walled (Figure 2J).

Root anatomy: In the root cross sections of secondary structure of taxon Marrubium bourgaei, protective tissue (periderm), cortex and central cylinder areas were seen (Figure 3A). The protective tissue was comprised of periderm. Periderm contained 8-10 layers of phellem cells with smooth outermost walls and bended radial walls (Figure 3B), a phellogen composed of radially layered thin walled cells and a phelloderm layer consisting of 1-2 cell layers. The cortex was generally comprised of large, thick-walled, oval or rectangular parenchyma cells. At the center was a nucleus consisting of tracheids (Figure 3C)

Leaf, stem and root anatomy in Marrubium heterodon: Leaf anatomy: The samples of Marrubium heterodon were collected from the vicinity of Medetsiz hill, situated at Pozant locality in Adana province of Turkey. In leaf cross section examinations, leaves were bifacial (dorsiventral) (Figure 4A). 2-3 layers of collenchyma cells were found in the midrib located between the upper and lower epidermis. A 
thick, wavy cuticula was observed outside the epidermis in TEM examinations (Figure 4B). 1-2 layers of palisade parenchyma cells were observed in the mesophyll tissue composed of palisade and sponge parenchyma cells located beneath the upper epidermis consisting of large cells (Figure 4C). Beneath the mesophyll tissue were 1-2 layers of sponge parenchyma with large intercellular spaces. Small vascular bundles were embedded in the mesophyll and they were collateral type (Figure 4D). Leaf mesophyll thickness was $200 \mu \mathrm{m}$ (Table 1). Stomata occurred at the same level as the epidermis (Figure 4E). Epidermis had glandular hairs (Figure 4F). Top and bottom surfaces of the leaves were covered with abundant eglandular and branch hairs. Abundant simple conical hairs were being formed at the same area (Figures 4G-I). Three different forms of glandular hairs were observed as; those with a short stem and very large crown (Figure 4J), those with a short stem and smaller crown area (Figure $5 \mathrm{~K}$ ) and those with a very long stem (Figures $4 \mathrm{~F}$ and L). In the surface views from the leaf (the lower and the upper), the leaves were amphistomatic. Stomata were anomocytic as indicated by neighbouring cells. Epidermis cells had wavy walls (Figure 4M). In the surface views from the leaf (the lower and the upper), the numbers of epidermis per $\mathrm{mm}^{2}$ were 500 and 700 , the numbers of stomata per $\mathrm{mm}^{2}$ were 102 and 100 , respectively. Lower and upper surface stomatal indexes were 16.94 and 12.5 , respectively. Stomatal index ratio was 0.73 (Table 1). A high number of starch grains and prismatic crystals were observed in the palisade parenchyma cells and sponge parenchyma cells with large intercellular spaces (Figures $4 \mathrm{O}$ and $\mathrm{P}$ ).

Stem anatomy: The stem was surrounded by a single layer of rectangular epidermis with a thick cuticula (Figure 5A). In each of the corners, 5-6 layers of lamellar collenchyma were seen beneath the epidermis cells (Figure 5B). Multicellular branched eglandular and glandular hairs were distributed throughout the entire stem. Lower and upper tangential walls of epidermis cells were thickened (Figures 5C and D). Lamellar collenchyma cells were thick-walled (Figure 5E). Stomata were observed in local areas of epidermis (Figure 5F). Vascular bundles were collateral type (Figure 5G). Beneath the cortex parenchyma, small groups of phloem sclerenchyma cells were located above the phloem. 2-3 layers of vascular cambium were located below the phloem. Xylem elements were highly thick-walled (Figure 5H).

Root anatomy: In the root cross sections of secondary structure of taxon Marrubium heterodon, protective tissue (periderm), cortex and central cylinder areas were seen (Figure 6A). The protective tissue was comprised of periderm. Periderm contained 8-10 layers of phellem cells with smooth outermost walls and bended radial walls, a phellogen composed of radially layered thin-walled cells and a phelloderm layer consisting of 1-2 cell layers (Figure 6B). Phellem cells were thick-walled and electron-dense in TEM examinations (Figure 6C). At the center was a nucleus consisting of tracheids (Figure 6D).

\section{Discussion}

The present study aimed to identify anatomical, histological and cytological features of the leaf, stem and root in Marrubium bourgaei and M. heterodon taxa of Marrubium L. genus from Lamiaceae family. Leaves of both taxa were examined with respect to the anatomical features of epidermis, stoma, mesophyll tissue, vascular bundles, leaf thickness and hair types and anatomical characteristics of the taxa were compared (Table 1). Leaf anatomical features were similar in both taxa. The leaves were amphistomatic and hypostomatic type. Stomata were amaryllis type and anomocytic as indicated by neighbouring cells. The leaves of the examined Marrubium species were bifacial (dorsiventral). In the surface views from the leaves (the lower and the upper) of Marrubium bourgaei and M. heterodon taxa, epidermis cells were slightly wavy-walled or polygonal. Simple pits were seen on the wavy-walled epidermis. In M. Heteredon, the number of epidermis per $\mathrm{mm}^{2}$ in upper surface was higher than that of lower surface and the number of stomata per $\mathrm{mm}^{2}$ in lower surface was higher than that of upper surface. However, no counts of epidermis and stomata could be performed in the surface sections of $M$. bourgaei due to intense cover of eglandular hairs.

Plants of Lamiaceae family are reported to have hairs in all surfaces. These hairs are in the form of both eglandular and glandular hairs. Different types of hairs are also recorded in the members of the family besides capitate multicellular glandular hairs (Özörgücü et al., 1991; Özdemir and Şenel, 1999; Satıl and Kaya 2007; Lakušıć et al., 2007; Dinç and Ozturk, 2008; Shan-Shan et. al., 2008; Hatamneia et. al., 2008; Kahraman et al., 2009; Celep et. al., 2011; Waly and Gayed, 2012; Dehshiri and Azadbakht, 2012; El-Deen Osman, 2012; Rusydi 2013; Arcia Do Rocio Duarte and Carvalho De Souza 2014; Mousavı et. al., 2014; Yetişen, 2014).

The differentiation between the palisade and sponge parenchyma cells forming the mesophyll tissue was prominent in both taxa. In both taxa, palisade parenchyma cells were oval and rounded in upper surface of the leaf and sponge parenchyma cells had large intercellular spaces in the lower surface of the leaf. In terms of leaf thickness, the leaves of $M$. bourgaei were thicker than those of $M$. heterodon (Table 1). In both taxa, leaf mesophyll thickness increased in the areas around the midrib. In leaf cross sections, vascular bundles were collateral type in both $M$. bourgaei and M. heterodon taxa and phloem surrounded xylem. Several layers of collenchyma cells were found between the upper and lower epidermis in both taxa.

In the stem cross sections, the stems were generally rectangular. Epidermis consisted of a single row of densely packed, oval cells. Stomata were observed in local areas of the epidermis. Several layers of lamellar collenchyma were seen beneath the epidermis. The wall properties of the collenchyma tissue change at the vascular bundle side.

Watson and Dallwitz, (1978) reported that members of Lamiaceae family have angular stems as a characteristic feature. Especially in each of the stem corners, a well developed collenchyma tissue was observed (Metcalfe and Chalk, 1972; Özörgücü et al., 1991; Uysal, 1991; Kandemir, 2003; Baran and Özdemir, 2006; Kahraman et al., 2010).

Cortex was parenchymatic and consisted of sclerenchyma cells. In the stem cortex were thin-walled parenchyma cells beneath collenchyma. The vascular bundles were collateral type, xylem was positioned towards the center, phloem was positioned towards the epidermis and there were few phloem elements. Cambium consisted of 1-2 layers of thin-walled cells. The nucleus area was parenchymatic and surrounded by vascular bundles. As a result, while there were differences in mesophyll thickness and the numbers of epidermis and stomata, cell appearances and structures were similar in Marrubium bourgaei and $M$. heterodon taxa of genus Marrubium L.

In root cross sections of both taxa, protective tissue was comprised of periderm and at the center consisting of tracheids. Both taxa had woody roots with secondary growth. 


\section{Materials and Methods}

\section{Plant materials}

The plants of Marrubium bourgaei and M. heterodon taxa of genus Marrubium (Figures 7A-D) were collected from the field. The leaves of each taxon were stored in $70 \%$ alcohol and examined with respect to the anatomical features of epidermis, stoma, mesophyll tissue, vascular bundles, leaf thickness and hair types to identify anatomical differences and similarities between the taxa (Table 2).

\section{Transmission Electron Microscopy}

Small samples of the leaves (lower, medium and upper parts), stem and roots taken from each taxon were first fixed with $3 \%$ glutaraldehyde and then with $1 \%$ osmium tetroxide. Following dehydration and saturation, samples were embedded in Epon 812 (Luft, 1961). Semi-thin sections were taken from these blocks with ultramicrotome by using glass knives and the sections were stained with methylene blue and toluidine blue. Ultrathin sections were first stained with uranyl acetate and lead citrate (Stempak and Ward, 1964) then examined with JEOL1 CX-100 TEM.

\section{Anatomical methods}

Surface sections could not be taken from Marrubium bourgaei. For surface views, a total of 20 surface sections (from lower and top sides of five randomly selected leaves per each taxon) were taken by hand. The hairs on the lower and upper parts were cut to reach the epidermis. In the sections taken, number of epidermal cells and stomata per $\mathrm{mm} 2$ were counted for calculation of stomatal indexes and stomatal index rates based on the formula below (Okay et al., 2000).

Stomatal index $=$ number of stomata per $\mathrm{mm}^{2} /$ number of stomata per $\mathrm{mm}^{2}+$ number of epidermal cells per $\mathrm{mm}^{2}$

Stomatal Index Ratio = upper stomatal index $/$ lower stomatal index

Leica DM500 light microscope was used for examinations and photographs were taken by ICC50 digital camera. For cross section views, 5 cross sections were taken from each of 5 randomly selected leaves per each taxon and average leaf blade thickness $(\mu \mathrm{m})$ was measured.

\section{Conclusion}

The present study, the anatomical characteristics of Marrubium bourgaei and $M$. heterodon taxa of genus Marrubium for leaves, stems and roots were determined. Anatomical features of both taxa are presented for the first time in this study. The leaves of the examined Marrubium species were bifacial (dorsiventral) and a high number of prismatic crystals were observed in the leaf mesophyll tissue. According to results, stem, leaf and root anatomical features provide useful characters for distinguishing species in the genus Marrubium.

\section{References}

Akgül G (2004) The revision of the genus Marrubium L. (Lamiaceae) of Turkey $\mathrm{Ph}$. D. thesis, Institute of science and technology, Ankara University, Ankara-Turkey.

Akgül G, Ketenoglu O, Pınar NM, Kurt L. (2008) Pollen and seed morphology of the genus Marrubium L. (Labiatae) in
Turkey. Ann Bot Fenn. 45:1-10.

Arcia Do Rocio Duarte M, Danielle Carvalho De Souza (2014) Microscopic characters of the leaf and stem of Lavandula dentata L. (Lamiaceae). Microsc Res Techniq. 77:647-652.

Baran P, Özdemir C (2006) The morphological and anatomical characters of Salvia napifolia Jacq., in Turkey. Bangladesh J. Botany 35(1):77-84.

Celep F, Kahraman A, Atalay Z, Doğan M (2011) Morphology, anatomy and trichome properties of Lamium truncatum Boiss. (Lamiaceae) and their systematic implications. Aust J Crop Sci. 5(2):147-153.

Clive AS (1980) Plant taxonomy and biosistematics, Cambridge University press, London, pp. 272.

Dehshiri MM, Azadbakht M (2012) Anatomy of Iranian species Teucrium polium (Lamiaceae). J Biol Today's World 1(2): 93-98.

Dinc M, Ozturk M (2008) Comparative morphological, anatomical, and palynological studies on the genus Stachys L. sect. Ambleia Bentham (Lamiaceae) Species in Turkey. Turk J Bot. 32: 113-121.

El-Deen Osman AK (2012) Comparative anatomical and palynological studies on genus Ballota (Lamiaceae) from Egypt. J Med Plants Res. 6(47): 5797-5812.

Estilai A, Hatemi A (1990) Chromosome Number and Meiotic Behavior of Cultivated Chia, Salvia hispanica (Lamiaceae). Hortscience 25 (12): 1646-1647.

Foster S, Ducle JA (1990) Eastern/Central Medicinal Plants. Hougton Mifflın Company, p.70, Boston.

Hatamneia A, Khayami M, Mahmudzadeh A, Sarghein SH, Heidarih M (2008) Comparative anatomical studies of some genera of Lamiaceae family in West Azarbaijin. Iran Bot Res J. 1(3): 63-67.

Hedge IC (1992) A global survey of the biogeography of the Labiatae. In: Harley RM

and Reynolds T (ed). Advances in Labiatae Science (7-17), Royal Botanic Gardens.

Heywood VH (1978) Flowering plants of the world. OUP Australia and New Zealand.

Kahraman A, Celep F, Dogan M (2009) Comparative morphology, anatomy and palynology of two Salvia L. Species (Lamiaceae) and their taxonomic implications. Bangladesh Association of Bangl J Plant Taxon. 16(1): 7382.

Kahraman A, Celep F, Doğan M (2010) Anatomy, trichome morphology and palynology of Salvia chrysophylla Stapf (Lamiaceae). S Afr J Bot. 76:187-195.

Kandemir N (2003) The morphological, anatomical and karyological properties of endemic Salvia hypargeia Fich. $\&$ mey. (Lamiaceae) in Turkey. Pak J Bot. 35:219-236.

Komarov VL. (1964) Flora of U.S.S.R, vol. XIV, p. 155-165, Jerusalem: Israel Program for Scientific Translations (English translation). 14:155-165.

Lakušić B, Lakušić D, Slavkovska V, Stevanović V, Stevanović B (2007) Morpho-anatomical differentiation of The Balkan endemic species Teucrium arduini L. (Lamiaceae). Arch Biol Sci. 59 (4): 369-381.

Leung A (1980) Encylopedia of Common Natural Ingredients: Used in Food. Drugs and Cosmetics. Toronto: Wilay-Intescience Publication, 199-200.

Luft JH (1961) Improvements in epox yresin embedding methods. J Biophys Biochem Cy. 9: 409.

Metcalfe CR, Chalk L (1972) Anatomy of the dicotyledons, 2. Clarendon Press, Oxford.

Mousavi SM, Jafari A, Najafi S (2014) Anatomical and micromorphological studies on leaves of salvia 1 . species in ne iran. Rom Biotech Lett. 19(1). 
Okay Y, Büyükkartal HN, Çölgeçen H (2000) An investigation on leaf anatomy of some Pistacia species. The herb J Syst Bot. 7: 161-177.

Özörgücü B, Gemici Y, Türkan İ (1991). Karşılaştırmalı Bitki Anatomisi, Ege Üniversitesi, Bornova, İzmir.

Özdemir C, Şenel G (1999). The morphological, anatomical and karyological properties of Salvia sclarea L. Turk J Bot. 23: 7-18.

Rusydi A, Talip N, Latip J, Abdul Rahman R, Sharif I (2013) Morphology of trichomes in Pogostemon cablin Benth. (Lamiaceae). Aust J Crop Sci. 7(6):744-749

Satıl F, Kaya A (2007) Leaf Anatomy And Hairs Of Turkish Satureja L. (Lamiaceae). Acta Biol Cracov Bot. 49(1): 6776.

Seybold S (1978) Revision Der Persischen Marrubium Arten (Labiatae). Stuttg. Beitr. Naturk. Ser. A (Biol.) 310: 9-22.
Shan-Shan H, Kirchoff BK, Liao JP (2008) The Capitate and Peltate Glandular Trichomes of Lavandula pinnata L. (Lamiaceae): Histochemistry, Ultrastructure and Secretion. The J Torrey Bot Soc. 135: 155-167.

Stempak JG, Ward RT (1964) An improved staining method for electron microscopy. J Cell Biol. 22: 697.

Tutin GT, Heywood VH 1964-1980. Flora Europaea. Vol. 13, Cambridge Univ. Press

Uysal İ (1991) Morphology, anatomy and ecology of endemic species of Sideritis trojana Bornm. Turk J Bot. 15: 371-379.

Yetişen K (2014) Morphological and anatomical study of the endemic species Phlomis monocephala (Lamiaceae). Phytol Balc. 20 (1): 49 - 55.

Waly NM, El Gayed SH (2012) Botanical and Biological Studies of Plectranthus tenuiflorus (Vatke) Agnew. (Lamiaceae) Growing In Saudi Arabia. IJLPR. 2(2): 52-64.

Watson L, Dallwitz MT (1978) The families of flowering plants. Oxford University press, London. 